\title{
Mediating Effect of Audit Quality in Relationship Between Auditor Ethics and Litigation: An Empirical Study
}

Submitted 1/12/18, $1^{\text {st }}$ revision $12 / 1 / 19,2^{\text {nd }}$ revision 23/2/19 accepted 24/3/19

\author{
Andi Agus ${ }^{1}$, Imam Ghozali ${ }^{2}$
}

\begin{abstract}
:
Purpose: This paper attempts to empirically examine the effect of auditor's ethics on litigation of audit results by using mediating variables of auditor quality.

Design/methodology/approach: This study considers a sample of 220 auditors working in public accounting firms using random survey methods. The main technique for analyzing data is Structural Equation Modeling.

Findings: The test results show that the auditor ethics has a positive and significant effect on audit quality, while auditor quality has a negative and significant effect on auditor's litigation.

Practical implications: The findings emphasize the importance of the ethical aspects of auditors' in conducting their tasks.

Originality/value: Audit quality in this study is able to strengthen the influence of auditor's ethics on auditor's litigation.
\end{abstract}

Keywords: Ethics, audit quality, litigation.

JEL Codes: M42, M48.

Paper type: Research paper.

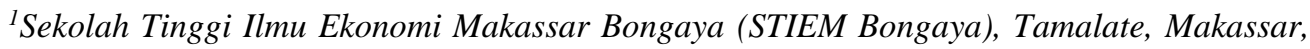
South Sulawesi 90131, Indonesia, e-mail: andiagus.stiembongaya@ gmail.com

${ }^{2}$ Department of Accounting, Faculty of Economics and Business, Diponegoro University, Semarang, 50275 Indonesia, email: imam.ghozali@live.undip.ac.id
} 


\section{Introduction}

Auditor litigation or lawsuits to auditors arise from parties who feel disadvantaged from low-quality financial statements. An example of this can be seen in Arthur Andersen being penalized by the United States Secutiries Exchange Commission (SEC) for being involved in creative accounting conducted by Enron Corporation (Barton, 2005). As a result of the case Arthur Andersen must prepare US $\$ 32$ billion to deal with various types of lawsuits from parties who feel disadvantaged. Similarly, Chuo Aoyama was penalized by the Japanese Financial Services Agency (JFSA) in Japan for being unable or failed to detect and uncover accounting frauds committed by the Kanebo company. In this case, it was revealed that Kanebo inflated profits of 200 billion Yen for the 1999-2003 fiscal year (Skinner and Srinivasan, 2010).

Another case was that the CDMG was dismissed and charged with US $\$ 2$ billion by Fanney Lee as a result of negligence and violation of the audit assignment contract. Penalty related to litigation risk can endanger the existence of KAP and threaten the auditor's personal assets. Holloway, Ingberman, and King (1995) suggest that litigation is expensive, the auditor will issue his wealth to pay for auditor litigation. Free (1999) found that litigation costs in the USA were around $14 \%$ of the gross fees received by auditors in 1992 and the level of auditor litigation increased by 300\% between 1985 - 1994 (Pratt and Stice, 1994).

Tangpinyoputtikhun and Thammavinyu (2010) found that CPA auditors who have high personal ethics will produce high audit quality. These findings are supported by Intakhan and Ussahawanichakit (2010) that auditors who have high ethical reasoning tend to pay attention to the public interest by providing high-quality audit reports to achieve audit effectiveness and better audit performance. Intakhan and Ussahawanitchakit (2009) found that auditors who have a high ethical orientation tend to act more independently and effectively to produce high audit quality. Researchers in the field of auditing argue that auditors improve audit quality to avoid litigation risk (DeFond, 2012).

This argument is in line with Hannes, Leone, and Miller (2008) which explains that high audit quality can maintain the benefits of reliable financial statements and avoid capital market penalties related to financial statements that cannot be trusted. The argument explains that high audit quality can increase the credibility of the client's financial statements, investor trust in the client's financial statements, client trust toward the auditor, and avoid clients and auditors from capital market penalties, and litigation from third parties who feel disadvantaged (Piot and Piera, 2002; Hakim, 2017). This paper seeks to examine empirically the effect of auditor ethics on litigation audit results mediated by the audit quality.

\section{Literature Review and Hypotheses}




\subsection{Auditor Ethics and the Litigation}

In auditing the financial statements, auditors must provide credibility and trust to stakeholders (Kurniawan, 2017). Auditing is very dependent on trust and fulfillment of auditor responsibilities, ethical considerations are very basic (Ardelean, 2013). The auditor's ethics relates to the auditor's ethical obligations. Ethical obligations serve as a guide for auditors in carrying out the obligation to provide and maintain audit quality with high standards (Ridaryanto et al., 2018; Sulistiyo and Ghozali, 2017; Suryanto and Thalassinos, 2017). The auditor's ethical obligation is to maintain the highest standards of ethical behavior which include integrity, objectivity, and independence in accordance with the professional code of ethics of accountants and responsible to the public, stakeholders, accounting profession, and organization. If the auditor has strategic resources, the auditor is motivated to maximize these resources to avoid litigation or lawsuits from parties who feel disadvantaged. The cause of litigation does not originate from low integrity and objectivity, but comes from negligence, inattention, or the failure of the auditor to maintain audit paperwork, review results or intentionally destroy the audit document used, and if the auditor does not provide a going concern statement even though the auditor believes the client will experience bankruptcy.

\section{H1. Auditor ethics has a negative and significant influence on litigation.}

\subsection{Auditor Ethics and Audit Quality}

The ethical problem of auditors in audits is related to the practice of moral violations committed by accountants, both those carried out by public accountants, management accountants, and government accountants. Ethical issues are also related to public trust in the accounting profession in carrying out their duties and responsibilities. Mansouri et al. (2009), Sunyoto and Ghozali (2018) explained that auditors play an important role in society to create stakeholder trust that the auditor is free from the influence of other parties or creates doubts to stakeholders on the auditor's honesty.

Auditors have high ethics that can be used in conducting audits. Ethics possessed by auditors is integrity and objectivity in the form of honesty and obedience to regulations when carrying out audit tasks, daring to disclose matters which according to their considerations and beliefs need to be carried out when carrying out audit tasks, and carrying out audit duties in accordance with facts and not seeking errors or hide errors. The high integrity and objectivity possessed by auditors allows auditors to carry out audit tasks well through quality improvement.

H2. Auditor ethics has a positive and significant influence on audit quality.

\subsection{Auditor Quality and the Auditor litigation}


Low audit quality is an audit conducted by the auditor, in which the auditor performs an error or intentionally does not comply with the established standard of professional examination or ethics. This can be detrimental to interested parties to the audited financial statements. Therefore, the auditor must be accountable to clients and third parties for negligence and / or breach of contract for failure to provide service or inattention in work (Arens and Loebbecke, 2011). Furthermore, Arens and Loebbecke (2011) explain that professional auditors have a legal responsibility to fulfill the implied or explicit contract with the client. That is, the auditor's responsibility to the client is in accordance with the contract law and is limited to breach of contract. The legal claims that afflict auditors mostly originate from financial report issues that have been published (Lastanti, 2005). The main cause is low audit quality.

\section{H3. Auditor quality has a negative and significant effect on quality.}

\subsection{Mediation Effects of Audit Quality}

Professional knowledge and auditor ethicss are core resources owned by auditors. Professional capital knowledge and auditor ethics are the strategic values of the auditor to produce audit quality. Ownership of professional knowledge and auditor ethics is used by auditors to improve audit quality and achieve sustainable competitive advantage through performance improvements. The auditor's moral responsibility is contained in SA 200 A15 (IAPI, 2013) which regulates the auditor's professional quality criteria which include; integrity, objectivity, confidentiality and professional behavior. As well as SA 200 A16 (IAPI, 2013) requires that the auditor must be independent of the entity being audited. Integrity in this case can be interpreted that the auditor in every analysis of audit evidence and preparing audit reports in an honest condition. This is in line with Gray et al. (1997) explaining that honesty, responsibility, transparency, and accountability are the principles of auditor integrity. Thus, the use of auditor ethicss in audit assignments teaches professional auditors to complete audit work honestly, morally, and with high quality.

H4. Auditor quality mediates the effect of auditor ethics on the auditor litigation.

\section{Methodology}

The data used in this study are primary data obtained from the results of questionnaire surveys on respondents, namely auditors who work in the Public Accounting Firm (KAP) registered at the IAI-KAP Directory in 2013. The population of the study is the auditor who works for KAP in Indonesia. Based on the 2013 IAI-KAP Directory, there were 409 KAP in all regions of Indonesia. The sampling technique was carried out with nonprobability sampling techniques, namely purposive sampling with the type of judgment sampling with certain criteria. 
The minimum sample size for SEM analysis with the Maximum Likelihood estimation method is 100 to 200 (Ghozali, 2011). The number of samples used in this study is 220 samples, which means the number of samples has exceeded the sufficient number of samples in SEM analysis. The number of samples in this study were 220 auditors who worked in public accounting offices in several major cities in Indonesia. Survey method by sending questionnaires to respondents who are used to collect data about; professional knowledge, auditor ethics, client pressure, audit quality, and auditor litigation.

The main technique for analyzing data is a structural equation model (Structural Equation Modeling / SEM). Data processing is done using the Statistical Package for Social Science (SPSS) application program version 22 and Analysis of Moment Structure (AMOS) version 22.

\section{Results}

\subsection{Normality Test}

Normality test in SEM analysis is intended to determine the normal distribution of research for each variable. Normality evaluation is carried out using the criterion of critical skewness value, data is said to be normally distributed if the value of the critical ratio skewness value is below the absolute price of 2.58 (Ghozali, 2011), while Ferdinand (2002) states that the value of C.R multivariate below 8 is acceptable and the analysis can still be continued as long as all indicators have a C.R kurtosis value $-2.58<\mathrm{z}<2.58$.

The results of the normality test show that the research data is normally distributed because the univariate C.R skewness values of all variables have been in the interval of $-2.58<\mathrm{z}<2.58$ so it can be concluded that the data analyzed has met univariate normality, furthermore, the multivariate C.R value has also been is in the range of $2.58<\mathrm{z}<2.58$ so that multivariate can be declared normal, thus it can be concluded that the research data also fulfills the assumption of multivariate normality.

\subsection{Test the Validity of Exogenous Constructs}

Exogenous construct validity test is done by looking at the value of the Loading Factor of each indicator in the exogenous construct. In this test the indicator is declared valid if it has the value of Loading Factor $>0.5$, while the exogenous construct reliability test is done by calculating the AVE value and C.R exogenous construct. In this test the exogenous construct is declared reliable if the AVE model $>0.5$ and C.R model > 0.7. Moreover, the results of structural model estimates show that model modification has a probability above 0.05 , thus, the model has been used properly to test the hypothesis in this study.

\subsection{Goodness of Fit Indices}


Goodness of fit is done to evaluate the suitability of the model by examining various criteria. A model is said to be fit if the matrix covariance of a model is the same as the data matrix covariance. Evaluation of goodness of fit is to assess whether the data to be processed meets the assumptions of structural equation models. There are three basic assumptions that must be met to be able to use structural equation models, namely: (1) independent data observation, (2) respondents taken randomly, (3) have a linear relationship. Before the data is processed, it is necessary to test whether there are data outliers, and the assumption of normality of data.

Table 1. Goodness of Fit

\begin{tabular}{|l|c|c|c|}
\hline Index & Cut-off value & Results & Information \\
\hline Chi-square & small & 62.219 & Good \\
\hline Prob. & $\geq 0.05$ & 0.068 & Good \\
\hline CMIN/DF & $\leq 2.00$ & 1.324 & Good \\
\hline TLI & $\geq 0.95$ & 0.992 & Good \\
\hline GFI & $\geq 0.90$ & 0.957 & Good \\
\hline AGFI & $\geq 0.90$ & 0.928 & Good \\
\hline RMSEA & $\leq 0.08$ & 0.038 & Good \\
\hline
\end{tabular}

Based on the test results, the Chi-square value is 62.219 , the significance probability of 0.068 is considered good because it is below the cut-off value nilai $0.05, \mathrm{CMIN} /$ DF $1.324(.002 .00)$, TLI $0.992(\geq 0.95)$, GFI $0.957(\geq 0.90)$, AGFI $0.928(\geq 0.90)$, and RMSEA $0.038(\leq 0.08)$. Based on these results, the model in this study is fit.

\subsection{Hypothesis testing}

Hypothesis testing is done by testing the level of significance aimed at testing whether there is a significant effect of endogenous variables on endogenous variables. The hypotheses built in this test are as follows:

Ho: There is no significant effect of exogenous variables on endogenous variables. Ha: There is a significant effect of exogenous variables on endogenous variables.

With a significant level of 0.05 , Ho will be rejected if the significant value $(\mathrm{P})<0.05$ and C.R $>1.96$, whereas if the value is significant $(P)>0.05$ and C.R $<1.96$ then Ho is not rejected.

Table 2. Regression Weights

\begin{tabular}{|c|c|c|c|c|c|c|}
\hline \multicolumn{3}{|c|}{ Hypothesis } & Estimate & S.E. & C.R. & P \\
\hline QL & $\leftarrow$ & ET & .654 & .052 & 12.687 & $* * *$ \\
\hline LT & $\leftarrow$ & QL & -.593 & .090 & -6.600 & $* * *$ \\
\hline LT & $\leftarrow$ & ET & -.368 & .068 & -5.399 & $* * *$ \\
\hline
\end{tabular}




\begin{tabular}{|c|c|c|c|c|}
\hline Hypothesis & Estimate & S.E. & C.R. & P \\
\hline Note: LT: Auditor Litigation; QL: Audit Quality; ET: Auditor Ethics \\
\hline
\end{tabular}

Based on the results of statistical calculations, the value of $p$ value influence the auditor's ethical variable on audit quality (ET $\rightarrow \mathrm{QL})$ is significant (***) with C.R marked positive at 12,687 . Therefore, the $p$ value obtained $<0.05$ and C.R is positive and $>1.96$. The implication is that auditor ethics has a positive and significant effect on audit quality, the better the auditor ethicss, the higher the audit quality. So, the first hypothesis is accepted.

Furthermore, the second hypothesis states that there is a negative influence of audit quality on auditor litigation. The test results show the value of $\mathrm{p}$ value the influence of audit quality variable on auditor litigation (QL $\rightarrow \mathrm{LT}$ ) is significant (***) with C.R negative sign of $-6,600$. Because the $p$ value obtained $<0.05$ and C.R is negative and the absolute value is C.R $>1.96$. This means that the auditor's quality has a negative and significant effect on auditor litigation, the higher the audit quality, the lower the auditor's litigation. So, the second hypothesis is accepted.

The third hypothesis analyzes the negative influence of auditor ethics on auditor litigation. The results of the statistical test show the value of $p$ value the effect of the auditor's ethical variable on auditor litigation (ET $\rightarrow$ LT) is significant (***) with C.R marked negative at -5.399 . Because the value of the $p$ value obtained $<0.05$ and C.R is negative and the absolute value is C.R > 1.96. Thus, the auditor ethics has a negative and significant effect on auditor litigation, the better the auditor ethics, the lower the auditor's litigation. This means that the third hypothesis is accepted.

\subsection{Direct and Indirect Effects}

In this study, the audit quality variable acts as an intervening variable, to test whether the audit quality variable can mediate the influence of the auditor's ethics on auditor litigation, so the Sobel test can be conducted. The hypotheses used in the Sobel test are as follows:

Ho: Audit quality can mediate the influence of auditor ethics on auditor litigation. Ha: Audit quality cannot mediate the influence of auditor ethics on auditor litigation.

With a significance level of 0.05 , Ho is rejected if the p value of the Sobel test results is $<0.05$ or $t$ value $>1.96$, whereas if the $p$ value is $>0.05$ and $t$ value is $<1.96$ then Ho is not rejected.

Table 3. Sobel Test Results

\begin{tabular}{|c|c|c|c|c|c|}
\hline & Input & Test & Test Statistic & Std. Error & p-value \\
\hline$a$ & 0.815 & Sobel Test & -5.54901585 & 0.07843012 & 0.00 \\
\hline
\end{tabular}




\begin{tabular}{|c|c|c|c|c|c|}
\hline$b$ & -0.534 & Aroian Test & -5.53916318 & 0.07856963 & 0.00 \\
\hline$S_{a}$ & 0.052 & Goodman Test & -5.55892128 & 0.07829037 & 0.00 \\
\hline$S_{b}$ & 0.09 & & & & \\
\hline
\end{tabular}

Based on the results of the Sobel test above, the value of the Sobel test value of 0.00 is obtained. Because the value of $p$ value obtained is $<0.05$, Ho is rejected and it is concluded that audit quality can mediate the influence of auditor ethics on auditor litigation. The better the auditor's ethics, the higher the audit quality that will suppress the high litigation.

\section{Conclusion}

The results of the study revealed that there was a positive and significant influence of auditor ethics on audit quality. The next finding is that auditor quality has a negative and significant effect on auditor litigation. Furthermore, in the relationship between ethics and litigation, the findings also reveal that the auditor ethicss have a negative and significant effect on auditor litigation. The theoretical implication of this finding is that the better the auditor ethics, the higher the audit quality. Conversely, the better the auditor ethics, the lower the auditor's litigation. Similarly, the higher the audit quality, the lower the auditor's litigation. To examine the effect of the mediating variable of auditor quality in the relationship between ethics and litigation, the statistical results show that audit quality can mediate the influence of the auditor's ethics on auditor litigation. Theoretically, the better the auditor ethicss, the higher the audit quality that will suppress the auditor's high litigation.

This finding emphasizes the importance of the ethical aspects of auditors. In connection with the findings that ethics possessed by auditors can improve audit quality, the higher the auditor ethicss, the more it produces audit quality. Auditors apply ethics that have it in the form of integrity and objectivity in carrying out audits. The auditor has produced a high audit quality that is shown in the issuance of audit reports and auditor opinion based on the results of the audit carried out in accordance with auditing standards and the provisions of applicable laws, opinion formulation is based on the results of evaluation of conclusions drawn from audit evidence obtained and adequately documented in the auditor's working paper, and the audit report is presented objectively in accordance with the accounting provisions and submitted on time in accordance with the agreement.

\section{References:}

Ardelean, A. 2013. Auditors'Ethics and their Impact on Public Trust. Procedia - Social and Behavioral Science 92, 55-60.

Arens, A.A. and Loebbecke. J.K. 2011. Auditing: Integrated A roach (Indonesian Edition). Jakarta: Salemba Empat.

Barton, J. 2005. Who Cares about Auditor Reputation? Contemporary Accounting Research 22(3), 549-586. 
DeFond, M.L. 2012. The Consequences of Protecting Audit Partners' Personal Assets from the Threat of Liability: A Discussion. Journal of Accounting and Economics 54, 174-179.

Ferdinand, A. 2002. Structural equation modeling dalam penelitian manajemen. Semarang: Baand Penerbit Universitas Diponegoro.

Free, C. 1999. Limiting Auditor Liability. Bond Law Review, No. 11, 118-135.

Ghozali, I. 2011. Model Persamaan Struktural Konsep and Aplikasi dengan Program Amos 19. Baand Penerbit Universitas Diponegoro, Semarang.

Gray, R., Dey, C., Owen, D., Evans, R. and Zadek, S. 1997. Struggling with the praxis of social accounting: Stakeholders, accountability, audits and procedures. Accounting, Auditing and Accountability Journal, 10(3), 325-364.

Hakim, F. 2017. The Influence of non-performing loan and loan to deposit ratio on the level of conventional bank health in Indonesia. Arthatama: Journal of Business Management and Accounting, 1(1), 35-49.

Hannes, K., Leone, A., and Miller, B. 2008. The Importance of Distinguishing Errors from Irregularities in Restatement Research: The Case of Restatements and CEO/CFO turnover. The Accounting review, 83(6), 1487-1520.

Harahap, P. 2018. The Executability of Arbitration Award by Judicial Institutions. Jurnal Hukum dan Peradilan, 7(1), 127-150.

Holloway, J.A., Ingberman, D.E. and King, R.R. 1995. Settlement Incentives under the Securities Exchange Act of 1934: Do the Merits matter? Working Paper, Washington University St Louis.

Institut Akuntan Publik Indonesia (IAPI). 2013. Standar Audit 200 Tujuan Keseluruhan Auditor Independen and Pelaksanaan Audit Berdasarkan Standar Audit. Salemba Empat: Jakarta.

Intakhan, P. and Ussahawanitchakit, P. 2009. Impacts of Professional Commitment and Ethical Orientation on Audit Independence and Audit Quality via a Moderator of Professional responsibility: Evidence from CPAs in Thailand. International Journal of Business Research 10(4), 1-14.

Intakhan, P. and Ussahawanitchakit, P. 2010. Roles of Audit Experience and Ethical Reasoning in Audit Profesionalisme and Audit Effectiveness Through a Moderator of Stakeholders Pressure an Empirical Study of Tax Auditor in Thailand. Journal of Academy of Business and Economics 10(5), 1-14.

Kurniawan, R. 2017. Effect of environmental performance on environmental disclosures of manufacturing, mining and plantation companies listed in Indonesia stock exchange. Arthatama Journal of Business Management and Accounting, 1(1), 6-17.

Lastanti, S.H. 2005. Review of Competence and Independence of Public Accountants: Reflections on Financial Scandals. Media Riset Akuntansi, Auditing, dan Informasi 5(1), 85-97.

Mansouri, A., Pirayesh, R. and Salehi, M. 2009. Audit Competence and Audit Quality: Case in Emerging Economy. International Journal of Business and Management 4(2), 1725.

Piot, C. and Piera, F. M. 2002. Corporate Governance, Audit Quality and the Cost of Debt Financing of French Listed Companies.

Pratt, J. and J. Stice. 1994. The Effects of Client Characteristics on Auditor Litigation Risk Judgment, Required Audit Evidence, and Recommended Audit Fees. Accounting Review 68, 639-656. 
Ridaryanto, P., Ghozali, I. and Purwanto, A. 2018. Assessing organizational justice and job satisfaction in public accounting firms in Indonesia. Quality - Access to Success 19(166), 94-98.

Skinner, D.J. and Srinivasan, S. 2012. Audit Quality and Auditor Reputation: Evidence from Japan. The Accounting Review, 87(5), 1737-1765.

Sulistiyo, H. and Ghozali, I. 2017. The role of religious control in dysfunctional audit behavior: An empirical study of auditors of public accounting firm in Indonesia. Journal of Applied Business Research, 33(5), 1047-1058.

Sunyoto, Y., Ghozali, I. and Purwanto, A. 2017. Analysis of Auditor Performance by Using Covariance Based Structural Equation Modeling: A Study of Public Accounting Firms in Indonesia. European Research Studies Journal 20(3), 524-537.

Suryanto, T., Thalassinos, I.E. 2017. Cultural Ethics and Consequences in Whistle-Blowing among Professional Accountants: An Empirical Analysis. Journal of Applied Economic Sciences, 6(52), 1725-1731.

Tangpinyoputtikhun. Y. and Thammavinyu, C. 2010. The Impact of Professional Knowledge and Personal Ethics on Audit Quality and Sustainable Reputation of Thai-Public Accountants. Journal of Academy of Business and Economics, 10(2), 1-20. 